\title{
MICHAL PULLMANN A FILOSOFICKÉ ASPEKTY SPORU O CHARAKTER NORMALIZACE
}

Není obvyklé, aby se teoretická diskuse bez přímých vazeb na aktuální politickou situaci dostala na titulní stránky novin. Sporu o výklad normalizace, který v poslední době probíhá v českém veřejném prostoru, se to však opakovaně daří. ${ }^{1} \mathrm{~V}$ centru tohoto sporu stojí Michal Pullmann, který hlásá potřebu přehodnotit dosavadní přístup českých historiků (ale i společnosti jako celku) k období let 1968-1989. Podle něj je totiž naše interpretace nedávných dějin, reprezentovaná např́íklad Ústavem pro studium totalitních režimů, do značné míry pokřivená. Potíž je už v názvu dané instituce - podle Pullmanna pozdní socialismus jednoznačně nebyl „totalitním“ režimem. ${ }^{2}$ Sporný je však také fakt, že velká většina výzkumné práce se v letech po sametové revoluci zaměřila bud’ na dějiny disentu (např. Charty 77), anebo na charakter a metody státního represivního aparátu, zejména Státní bezpečnosti (StB). Podle Pullmanna tento př́stup zveličuje důležitost disentu, který byl v československé společnosti až do pozdních osmdesátých let pouze okrajovým fenoménem, a ignoruje „,normalizační každodennost“ - tedy svět, ve kterém fungovala velká většina tehdejší populace. ${ }^{3}$ Výsledkem je podle Pullmanna pokřivený obraz této doby, vytvářející umělou propast mezi (opresivním) režimem a (pasivně trpící) společností, jenž zastírá mnohem pestřejší realitu.

Situace, kdy spor mezi historiky poslouží jako nosný námět filosofického článku, není úplně běžná, nezávisle na tom, jak výrazně rezonuje u široké veřejnosti. U sporu o charakter normalizace, zejména jak jej prezentuje právě Pullmann, to však neplatí. Důvod je poměrně jednoduchý. Vyhroceně řečeno, i povrchnímu čtenáři Pullmannových prací ${ }^{4}$

1 Viz např. Respekt, 33, 2020, kde je tomuto sporu věnována titulní strana, téma čísla i několik dalších článků.

2 P. Kolár̆ - M. Pullmann (vyd.), Co byla normalizace? Studie o pozdním socialismu, Praha 2016, str. 12.

3 Tamt., str. 38-48.

4 Pro zachování odborné roviny diskuse nebudu v tomto článku citovat z výstupů M. Pullmanna určených širší veřejnosti, např. z řady rozhovorů, které poskytl 
musí být jasné, že ho jako historika „normalizační každodennost“ sama o sobě vlastně nezajímá, respektive ho zajímá jenom okrajově. Jeho ambicí není zkoumat detaily hospodské, chatové či trampské kultury v Československu. Ve svých publikacích neanalyzuje každodenní život dělníků ani jiných skupin obyvatelstva. A pokud na otázky normalizační každodennosti přece jen narazí, většinou odkazuje na práce jiných historiků - např́íklad na knihu Pauliny Bren Zelinář a jeho televize. Kultura komunismu po pražském jaru 1968.5

Pullmanna ve skutečnosti zajímá něco odlišného, a to konceptuální uchopení charakteru komunistického režimu a jeho působení v rámci československé společnosti. Významnou, ne-li zásadní roli v jeho argumentaci proto hraje několik klíčových politicko-filosofických pojmů, z nichž vychází jím předkládaný obraz normalizace. Jsou jimi idea „společenského konsensu“, představa „stabilního politického uspořádání“, jež má určitou „legitimitu“ vycházející ze „společenské smlouvy“ mezi režimem a obyvateli založené na jisté formě ,tichého souhlasu“. Důležitou roli u Pullmanna hraje také analýza užití ideologického jazyka a jeho performativní funkce v rámci politických vztahů.

Pullmannovy práce proto není možné chápat jako čistě historické. Ve svých textech totiž implicitně (ale často i explicitně) hájí stanoviska, která tradičně patří do oboru politické filosofie. Takto interdisciplinární přesah historické práce samozřjejmě není problematický, je naopak vítanou (a možná i nutnou) součástí jakékoli komplexní analýzy nedávné minulosti. Zároveň to však znamená, že je Pullmannovy texty možné podrobit kritické reflexi i z ne-historické, filosofické perspektivy - a přesně o to se pokouší tento prríspěvek.

Následující text je rozčleněn do tří částí. V první sleduji již výše uvedenou otázku „konsensu“ v rámci normalizační společnosti a s ní

českým médiím. Budu vycházet zejména z monografie M. Pullmann, Konec experimentu, Praha 2011. Dalším významným zdrojem bude již citovaný sborník P. Kolář M. Pullmann (vyd.), Co byla normalizace?. Ten obsahuje řadu studií, jež Pullmann publikoval v různých domácích i zahraničních historických časopisech. Rovněž budu používat studie, které v rámci daného sborníku Pullmann publikoval společně s Pavlem Kolářem. Na několika místech z daného sborníku cituji i práce, které napsal Kolář samostatně. Pokud jde o výklad doby normalizace, předkládá sborník dosti jednotnou pozici, proto na něj v tomto článku budu odkazovat jako na celek, nikoli na jeho jednotlivé části.

5 P. Bren, Zelinář a jeho televize. Kultura komunismu po pražském jaru 1968, Praha 2013. Pro krátký referující přehled historiků věnujících se různým aspektům normalizační každodennosti viz P. Kolář - M. Pullmann (vyd.), Co byla normalizace?, str. 34 . 
spojený problém politické legitimity tehdejšího režimu. V první řadě vykreslím představu „tichého souhlasu“ naší společnosti s tehdejším režimem, jak ji Pullmann prezentuje napříč svými texty. Následně budu analyzovat problémy, jež jeho filosoficko-historická koncepce normalizace navázaná na zmíněný konsensus obnáší. Druhá část článku je věnovaná ideologickému ,hypernormalizovanému“ jazyku a jeho funkci. Zde poukáži na paralely Pullmannova hlavního argumentu z knihy Konec experimentu a Havlovy analýzy funkce ideologického jazyka z Moci bezmocných. Argumentační postup obou textů vykazuje - do jisté míry překvapivě - značnou míru podobnosti, ovšem s diametrálně odlišnými závěry. Jejich komparace proto umožní zasadit Pullmannovu argumentaci do širšího kontextu české filosofie, a tak jí lépe porozumět a kriticky ji zhodnotit. Závěr příspěvku tvoří obecnější filosofická analýza vládnutí v podmínkách absence legitimity, jež vůči Pullmannově koncepci načrtává alternativní porozumění mocenským vztahům v letech 1968-1989.

\section{Legitimita a konsensus v podmínkách diktatury}

Pullmannova monografie Konec experimentu přináší poutavý a detailní pohled na postupný rozklad ideologického jazyka používaného komunistickou nomenklaturou. Ukazuje, jak vedení státu i strany tápalo při zavádění (ze Sovětského svazu nařízené) „přestavby“ systému reálného socialismu. Zejména „hypernormalizovaný“ ideologický jazyk, který dominoval veřejnému prostoru od raných sedmdesátých let, byl slovníkem přestavby vážně narušen. Např́klad zavádění (omezených) tržních principů do ekonomiky nastolovalo znepokojivé otázky, zejména „,o vlastně socialismus znamená“. ${ }^{6} \mathrm{Na}$ výzvy tohoto typu však zkostnatělé vedení státu nebylo schopno přinášet smysluplné odpovědi. To v obyvatelstvu posilovalo dojem, že ,ideologické výrazy jsou jen nefunkční a prázdnou skořápkou“. ${ }^{7}$ Monolit ideologického jazyka založeného na „opakování předem daných floskulî“8 se tedy v pozdních osmdesátých letech rozpadl, a tím připravil cestu pro ,implozi“ normalizačního režimu v listopadu $1989 .{ }^{9}$

$6 \quad$ M. Pullmann, Konec experimentu, str. 218. Kurziva v originálu.

7 Tamt., str. 198.

8 Tamt., str. 208.

9 Tamt., str. 218. 
Tolik minimalistické shrnutí Pullmannovy historické analýzy, která z mého laického pohledu vyznívá jako přesvědčivý a mimořádně zajímavý př́íspěvek ke zkoumání nedávných dějin. Jak jsem však již nastínil výše, všechny Pullmannovy texty k tomuto tématu obsahují také nepřehlédnutelný normativní rámec, který autorovi umožňuje nejenom situaci popsat, ale také ji (implicitně i explicitně) hodnotit. To se mimo jiné ukazuje při popisu krize ideologického jazyka, již Pullmann konzistentně napříč svým dílem popisuje jako „dezintegraci normalizačního konsensu“ ", „,narušení konsensu“11 či jako problém ,jak znovu dosáhnout konsensu“. ${ }^{12}$ Tyto (a mnohé podobné) formulace poukazují na silné autorovo přesvědčení, že zdejší normalizační režim byl výsledkem „,vnitřních společenských vztahů“, a nikoli „,dovozem z vnějška“13 - a že tedy „,, sociální oporou normalizačního režimu“ nebyla úzká vrstva byrokracie, nýbrž drtivá většina společnosti““. ${ }^{14}$ Jinak řečeno, Pullmann ve svých textech představuje konec osmdesátých let jako proces rozkladu funkčního a obyvatelstvem více méně přijímaného režimu kulminující v naprostou ztrátu prestiže, již tento režim dříve měl.

Jako opora tvrzení o normalizačním konsensu Pullmannovi slouží opakované poukazování na stabilitu politické situace a absenci opozičního jednání ze strany širokých vrstev společnosti. Pullmann (spolu se spoluautorem Pavlem Kolářem) tvrdí, že ,ve všech stabilních režimech, demokraciích i diktaturách existuje jistý ideologický konsensus“", 15 přičemž ,žádný politický řád se nemůže udržet, nedokáže-li získat alespoň pasivní podporu obyvatel a nestane-li se pro většinu z nich ,normálním““. ${ }^{16}$ To podle nich přesně vystihuje situaci v Československu. Pro jejich hodnocení normalizace a normalizačního režimu je proto zásadní, že ,i když normalizační režim nikdy nezískal otevřenou podporu společnosti, zároveň se až do pozdních osmdesátých let většina obyvatel ani nepostavila proti němu." 17 Zejména v našem prostředí tolik analyzovaný disent byl podle Pullmanna až do posledních měsíců před

\footnotetext{
10 Tamt., str. 92.

11 Tamt., str. 95.

12 Tamt., str. 113.

13 P. Kolár - M. Pullmann (vyd.), Co byla normalizace?, str. 9.

14 M. Pullmann, Konec experimentu, str. 223.

15 P. Kolár - M. Pullmann (vyd.), Co byla normalizace?, str. 54.

16 Tamt., str. 40.

17 Tamt., str. 44.
} 
revolucí pouze okrajovým fenoménem, který široké masy obyvatelstva vlastně nezajímal. ${ }^{18}$

Vzájemně provázané odkazy na stabilitu a ideologický konsensus umožňují Pullmannovi vynášet další propojené normativní soudy o charakteru režimu v normalizačním Československu. Vláda komunistické strany pro něj nebyla žádným násilným dovozem z vnějšku, nýbrž byla široce přijímána a pevně provázána se společností jako takovou - proto také píše o její legitimitě.$^{19}$ Opět (podobně jako u myšlenky společenského konsensu) se tak děje zejména v kontrastu s postupující krizí normalizačního režimu. Pullmann analyzuje „rozpad legitimity na konci osmdesátých let" ${ }^{20}$ který je však podle něj produktem až posledních předrevolučních měsíců. Píše například, že „,pojetí státu coby garanta bezpečí a spokojenosti ,slušných lidí““ zůstávalo v platnosti ještě v roce 1988, přičemž projevy nespokojenosti, objevující se tou dobou např. již i v Rudém právu, ,je nutno považovat spíš za výraz znejistění než odmítnutí panujícího systému legitimního násilî́. ${ }^{21}$ Jako oporu legitimity normalizačního režimu Pullmann také v návaznosti na práci Milana Otáhala používá termín „společenské smlouvy“, který má implikovat alespoň do jisté míry dobrovolný „,výměnný obchod“, v němž se lidé „,vzdali politických svobod, za něž získali sociální jistoty“.22

Pullmannovo opakované a časté používání významných politicko-filosofických termínů jako konsensus, legitimita či společenská smlouva prozrazuje jeho filosofický náhled na charakter a celkovou přijatelnost normalizačního režimu, jenž je založen na představě „tichého souhlasu“ populace s tímto režimem (což je ostatně termín, který autor sám používá). ${ }^{23}$ Pullmann zkrátka věří, že režim vládnoucí v Československu v sedmdesátých a osmdesátých letech (s výjimkou jejich úplného závěru) představoval stabilní, legitimní a všeobecně přijímané politické uspořádání, jež do velké míry reflektovalo charakter a přesvědčení tehdejší společnosti. A jelikož lidé v Československu „tiše souhlasili““ s politickými poměry - a dokonce se na nich extenzivně podíleli -, nemůžeme o komunistické diktatuře uvažovat jako o externím pachateli nelegitimního násilí na naší společnosti. Normalizační režim je pevnou

18 M. Pullmann, Konec experimentu, str. 221-225.

19 Tamt., str. 19.

20 P. Kolář - M. Pullmann (vyd.), Co byla normalizace?, str. 90.

21 Tamt., str. 91.

22 Tamt., str. 30. Viz také tamt., str. 68, 120.

23 Tamt., str. 60. 
součástí společenského vývoje u nás a naší vlastní historie, a proto bychom jej podle Pullmanna měli hodnotit daleko příznivěji, než je tomu v českém prostředí dnes běžné.

Normativní rámec sloužící Pullmannovi k hodnocení normalizačního režimu je však v mnoha ohledech problematický, jak se pokusím vysvětlit ve zbytku této kapitoly. V první řadě Pullmann zastává v současné filosofické literatuře výrazně menšinový názor, že i v podmínkách diktatury (a Pullmann ve svých textech konzistentně píše o „komunistické diktatuře“) 24 lze mluvit o „dosahování konsensu“ a „legitimitě“. Problém zde spočívá v tom, že situace v normalizačním Československu byla na hony vzdálená jakkoli definované „ideální řečové situaci“, 25 v níž by bylo možné rozumně diskutovat, uvádět protichůdná stanoviska, budovat argumentaci, a docházet tak ke společenskému konsensu, o kterém Pullmann opakovaně píše. Právě naopak: vládnoucí ideologie, ústavou definovaná vedoucí úloha komunistické strany a všudypřítomná cenzura spojená s absencí svobody slova a shromažd’ování vytvářely situaci, kdy utváření konsensu ve veřejném prostoru nebylo vlastně vůbec myslitelné.

Tohoto faktu si je Pullmann samozřejmě vědom, a proto ve svých textech k normalizačnímu „konsensu“ často přikládá další přívlastky. Píše např́íklad o „formálním konsensu“26 či o „předstíraném všeobecném konsensu“ “. ${ }^{27}$ Tyto fráze jsou však (přinejlepším) nepřiměřeným užitím jazyka. Jednoduše řečeno, pokud já prezentuji názor a ty máš pouze právo mlčet, tak jsme přece nedospěli k žádnému „formálnímu konsensu“, ve kterém jsme se shodli na mém názoru. Danou situaci není možné popsat jako konsensus jakéhokoli druhu. Tento závěr platí dvojnásob, pokud má slovo „konsensus“ vést k závěrům o legitimitě či přijatelnosti normalizačního režimu, případně o jakémsi ideovém propojení vlády a společnosti. Z „formálního“ či „předstíraného“ (pseudo)konsensu totiž na legitimitu či přijatelnost vlády usuzovat jednoznačně nelze. ${ }^{28}$

\footnotetext{
24 Tamt., str. 217.

25 J. Habermas, Theorie des kommunikativen Handelns, Frankfurt a. M. 1997.

26 M. Pullmann, Konec experimentu, str. 93.

27 Tamt., str. 105.

28 To je ostatně jeden z důvodů, proč mnozí političtí filosofové hájí názor, že v současném světě je funkční demokracie nutnou podmínkou politické legitimity. Viz např. A. Buchanan, Political Legitimacy and Democracy, in: Ethics, 112, 2002, str. 689-719; D. Estlund, Democratic Authority. A Philosophical Framework, Princeton 2009; T. Christiano, The Authority of Democracy, in: Journal of Political Philosophy, 12, 2004, str. 266-290.
} 
Pullmann si je jisté vratkosti svých prohlášení o legitimitě komunistické diktatury možná vědom, a proto se v tomto bodě zaštit'uje autoritou Maxe Webera. Právě jeho koncepci legitimity si se spoluautorem Pavlem Kolářem berou za základ svých úvah. Píší, že „Weber pod pojmem legitimity neměl na mysli otevřené potvrzení stávajícího pořádku většinou obyvatel, např. v demokratických volbách... Legitimní byl pro Webera každý systém, ve kterém výkon fyzického násilí státem není zpochybňován. Jinými slovy, Weber by byl i nacistický nebo stalinský režim býval považoval za ,legitimní‘, aby pochopil společenské mechanismy, které umožňovaly fungování zločinných institucí.“29 Právě ve „weberiánských“ intencích, které jsou prosté normativity, chtějí tedy Pullmann a Kolár analyzovat legitimitu normalizačního režimu.

Úkrok od normativních definic legitimity, kterým se rádi věnují filosofové, směrem k více deskriptivnímu, sociálně-vědeckému porozumění tohoto pojmu je samozrejmě možný. Pro historickou práci je takto sociologický přístup možná i adekvátnější než normativní, teoretické bádání. Problém je však v tom, že Pullmannova a Kolářova „weberovská“ pozice se zakládá na nepř́iliš přesvědčivé interpretaci tohoto myslitele. To podrobně ve své recenzi jejich publikace analyzuje Miloš Havelka; ${ }^{30}$ zde se zaměřím pouze na jeden zásadní bod z předešlého citátu. Kolář a Pullmann poznamenávají, že „legitimní byl pro Webera každý systém, ve kterém výkon fyzického násilí státem není zpochybňován“. To je ovšem pravda jen částečně. Weber píše, že klíčovým komponentem legitimní autority (Herrschaft) politických institucí je „víra v [jejich] legitimitu“ (Legitimitätsglaube) ${ }^{31}$ Legitimita u Webera tedy není záležitostí celkového hodnocení režimů - Webera zajímá postoj jednotlivce k politické autoritě. ${ }^{32}$ Proto i stalinský či nacistický režim by teoreticky mohly pro Webera být legitimní - ovšem za předpokladu, že by měly skutečnou podporu svých obyvatel. A právě zde se nachází kořen problému.

Kolář a Pullmann tvrdí, že pokud režim „nebyl zpochybňován“, pak to stačí na (weberovskou) legitimitu. Následně ukazují, že „ve společ-

29 P. Kolár - M. Pullmann (vyd.), Co byla normalizace?, str. 61.

30 M. Havelka, Ideologická kritika ideologické kritiky normalizace, in: Soudobé dějiny, 1-2, 2018, str. 239-241.

31 Viz M. Weber, Wirtschaft und Gesellschaft, Tübingen 1922, str. 122. Tato kniha je $\mathrm{k}$ dispozici i v novém anglickém překladu. Pro relevantní pasáže viz M. Weber, Economy and Society. A New Translation, přel. K. Tribe, Cambridge (Mass.) 2019, str. 339.

32 Viz napr. D. Beetham, Max Weber and the Legitimacy of the Modern State, in: Analyse \& Kritik, 13, 1991, str. 34-45. 
nosti po celou dobu ,normalizace“ nedošlo v podstatě k žádným nepokojům“, ${ }^{33}$ což stvrzuje jejich závěry. Tím se však dostáváme k problematické dvouznačnosti pojmu „zpochybnění“. Kolář a Pullmann mají jednoznačně pravdu v tom, že schopnost normalizačního režimu vykonávat monopol moci nebyla až do roku 1989 zpochybněna žádným masovým protestním hnutím. Je však možné v československé společnosti v období normalizace najít „nezpochybňovanou“ víru v autoritu Komunistické strany? To je těžko představitelné - o jakékoli pozitivně formulované „víre“" obyvatelstva v normalizační režim se v analyzovaných publikacích nedočteme. Kolář s Pullmannem navíc sami píší, jak jsem je citoval výše, že ,normalizační režim nikdy nezískal otevřenou podporu společnosti.“34

Spíše než vírou tehdejšího obyvatelstva v autoritu komunistického režimu se proto Pullmann napříc svým dílem zaštit’uje konformním jednáním. Opakovaně poukazuje na fakt, že politické uspořádání bylo stabilní a všeobecně považované za „normální“. Lidé si v něm jednoduše žili svými každodenními starostmi a mohli „uvést do svých životů poměrně vysokou míru nonkonformních postojů..., a přitom sebe sama považovat za dobré socialistické občany“ ${ }^{35}$ Když Pullmann analyzuje přijatelnost normalizačního režimu, nedívá se tedy na názory či postoje tehdejší populace a na její (weberovskou) víru v legitimitu vlády komunistické strany. Snaží se poukázat na něco, co bychom mohli nazvat ,praktickou afirmací“ - tedy na tichý souhlas ovládaných s vládou na rovině skutků spíše než přesvědčení.

Tento typ postoje není v politické filosofii nezvyklý. Obhajoba určité formy tichého souhlasu se objevuje již u Platónova Sókrata a její nejvlivnější verzi vypracoval v sedmnáctém století John Locke. Nap̌ríklad Platónův Sókratés v dialogu Kritón explicitně spojuje konformní jednání na rovině skutků s uznáním politické autority. Sókratés imituje hlas athénských zákonů a ř́ká, že „,kdo z vás zde zůstane, maje možnost viděti, jakým způsobem my soudíme a vůbec spravujeme obec, ten se s námi již, jak tvrdíme, skutkem dohodl, že bude dělat to, cokoli bychom přikazovaly“،.36 Dnešním jazykem řečeno, spokojený pobyt v obci pro

\footnotetext{
33 P. Kolár̆ - M. Pullmann (vyd.), Co byla normalizace?, str. 86.

34 Tamt., str. 44.

35 M. Pullmann, Konec experimentu, str. 219.

36 Platón, Crito, 51e (český překlad cit. podle: Platón, Euthyfrón, Obrana Sókrata, Kritón, přel. F. Novotný, Praha 2005, str. 90). Podobný argument přináší i J. Locke, Dvě pojednání o vládě, přel. J. Král - J. Popelová, Praha 1965, § 119.
} 
Sókrata představuje jistou formu praktické afirmace, jíž se stvrzuje legitimita daného politického uspořádání a autorita jeho zákonů.

Argumentace operující s tichým souhlasem či praktickou afirmací nicméně není v případě Pullmannova výkladu možná, a to $\mathrm{z}$ poměrně jednoduchého důvodu. Jak Locke, tak Sókratés totiž opakovaně zdůrazňují, že afirmace či tichý souhlas, mají-li být jakkoli relevantní, musí nutně obsahovat element svobodného rozhodnutí. Jinak tato afirmace zůstává, pokud užiji Pullmannova výrazu, „formální“, a nic z ní tedy nevyplývá.

Roli onoho elementu svobodného rozhodnutí hraje u Sókrata i Locka právo na emigraci. Tichý souhlas vzniká jenom v momentě, pokud ,žádný z nás, zákonů, nestojí v cestě a nezakazuje, jestliže někdo z vás chce jít do některé zahraniční osady, když bychom se mu my a obec nelíbily, nebo chce-li jít někam do ciziny a tam žít jako metoik“. ${ }^{37}$ Ve filosofické literatuře se pak spor vede zejména o to, jestli samotné právo na emigraci představuje dostatečný element svobodné volby, aby z tichého souhlasu udělal relevantní kategorii pro otázku politické legitimity. Např́íklad David Hume, nejznámější kritik Lockovy teorie tichého souhlasu, je přesvědčený, že to nestačí. Ve slavné pasáži píše: „Můžeme skutečně říct, že se chudý sedlák nebo řemeslník svobodně rozhoduje, zda odejde ze své země, když neovládá žádný cizí jazyk a obyčeje a žije ze dne na den ze svého nízkého výdělku? To můžeme rovnou tvrdit, že tím, že člověk zůstává na palubě lodi, svobodně souhlasí s nadvládou velitele; i když jej odnesli na palubu v spánku a musí skočit do oceánu a zahynout v momentě, když ji opustí.“"38

Jestli právo na emigraci je, nebo není dostatečnou podmínkou pro existenci tichého souhlasu, je však v kontextu normalizace veskrze akademickou otázkou. Režim, který na hranicích stř̌ilel vlastní občany, žádný prostor pro rozhodnutí nedával. Obyvatelé Československa byli proto jednoznačně v situaci Humova muže, kterého v hlubokém spánku přenesli na lod', jež v mezičase vyplula a ted’ se nachází uprostřed oceánu. Absence jakéhokoli elementu svobodného rozhodování znamená, že i následné smîrení velké části populace se svou situací nic nevypovídá o akceptaci či legitimitě normalizačního režimu.

Ve zkratce řečeno, Pullmannova pozice počítá implicitně se třemi mody interakce mezi obyvatelstvem a režimem. Jsou to (1) hlasitá pod-

37 Platón, Crito, 51d (cit. podle: Platón, Euthyfrón, Obrana Sókrata, Kritón, str. 90).

38 D. Hume, Political Essays, Cambridge 1994, str. 193. (Můj překlad.) 
pora, (2) hlasitý odpor a (3) tichá podpora. Přednesený výkladový model normalizace nepočítá s poslední logickou možností: s tichým odporem. Pullmann opakovaně konstatuje, že obyvatelé sice režim aktivně nepodporovali, ale ani se proti němu nebouřili, čímž (v rámci logiky daných tři možnostî́) docházelo $\mathrm{k}$ jakési akceptaci či tiché podpoře. To je však neodůvodněné tvrzení. Jak jsem ukázal v předcházejících odstavcích, existuje celá tradice uvažování o tom, jak je možné podporu vládě ustanovit pomocí ,tichého souhlasu“ a v jejím rámci pak uvažovat o legitimitě. Bez elementu svobodného rozhodnutí lze však jakoukoli, i tichou, podporu vykázat stěží. Musíme tedy uzavřít, že podobně jako „formální konsensus“ neposkytuje ani idea „tichého souhlasu“ či ,praktické afirmace“ dostatečnou oporu Pullmannovu hodnocení normalizačního režimu a jeho přijatelnosti - protože k žádnému relevantnímu souhlasu, přijetí či afirmaci nedochází.

Problematičnost uvažování o praktické afirmaci či tiché podpoře lze předvést i z další stránky. Klíčovým prvkem Pullmannovy analýzy normalizace, jak jsem již zmínil výše, je vyvracení představy o pacifikované společnosti vydané napospas moci komunistické diktatury. Pullmann píše, že lidé „,nebyli jen trpnou masou atomizovaných jedinců“, ale „snažili se prosazovat své zájmy pomocí důmyslně propracovaných strategiî““. ${ }^{39}$ Pavel Kolář pak explicitně tvrdí, že je nutné ,poopravit ... představu, že by společnost $\mathrm{v}$ komunistické diktatuře byla úplně bezmocná“.$^{40}$ To, že byl tento vztah ,asymetrický“, Pullmann samožrejmě nepopírá ${ }^{41}$ opakovaně však poukazuje na fakt, že společnost byla často schopna „mařit oficiální cíle a zároveň hájit své vlastní zájmy“. ${ }^{42}$

Tato tvrzení mají svou pevnou roli v pullmannovsko-kolářovském líčení normalizace. Pokud by se totiž ukázalo, že lidé skutečně mohli „mařit oficiální cíle“, ale zároveň se to prostě rozhodli nedělat a kooperovali s režimem, pak bychom vrátili do hry představu ,praktické afirmace“ i s elementem svobodného rozhodnutí. Následně bychom mohli říct, že společnost jistým způsobem přece jenom souhlasila s komunistickou diktaturou, která tak nebyla žádným externím, nelegitimním, mocenským vnucením, nýbrž reflexí tehdejších vnitrospolečenských vztahů a nálad. Nejjasněji tuto myšlenku vykládá Pavel Kolár̆, když píše:

\footnotetext{
39 P. Kolár - M. Pullmann (vyd.), Co byla normalizace?, str. 31.

40 Tamt., str. 117.

41 Tamt., str. 45.

42 Tamt., str. 33.
} 
„V Mad’arsku byly represe tak rozsáhlé, že v roce 1950 byl nějakým způsobem perzekvován milion lidí; to znamenalo, že represemi byla postižena každá třetí rodina. Takováto kolosální operace nemohla být pouze výsledkem nekalého záměru mocenského aparátu, musela se také opírat o sociální zájmy a podporu těch, kteří z ní profitovali. ... Moc v diktatuře nemůžeme chápat jako zónu přísně oddělenou od společnosti. Naopak, diktátorské panství bylo produktem společenských vztahů mezi vládnoucími a ovládanými, nikoli protipólem společnosti. ,Moc' zajisté mohla někoho zatknout a poslat do pracovního tábora. Avšak čistý nátlak nestačil k tomu, aby někoho přiměla stát se předsedou národního výboru, vedoucím ,brigády socialistické práce " nebo dobrovolným pomocníkem Veřejné bezpečnosti. A právě tyto ,nedobrovolně dobrovolné ‘ činnosti préedpokládaly určitou míru (neideologického) přitakání stávajícímu aranžmá. Představovaly průsečík mezi tím, co chtěla ,moc", a tím, co odpovídalo individuálním zájmům občanů.“43

Problematičnost pullmannovsko-kolářovského argumentu propojujícího kooperaci společnosti s „přitakáním stávajícímu aranžmá“ snad nejlépe vynikne v kontrastu s analýzou podobného fenoménu, již předkládá Hannah Arendtová. V nejmrazivějších pasážích Eichmanna v Jeruzalé$m e \check{~ p o p i s u j e ~ E i c h m a n n e m ~ o r g a n i z o v a n e ́ ~ z ̌ i d o v s k e ́ ~ t r a n s p o r t y, ~ k t e r e ́ ~ s e ~}$ v drtivé většině prrípadů obešly bez použití přímého násilí - „všechno probíhalo víceméně hladce a rychle se stalo rutinou“". ${ }^{44}$ Tato hladkost při organizaci transportů směřujících (povětšinou) do vyhlazovacích táborů byla zabezpečena tím, že se na ní do jisté míry podílela samotná židovská obec. Probíhalo to následovně:

„Eichmann nebo jeho lidé informovali židovské rady starších, kolik Židů je třeba k naplnění vlaků, a židovští starší zhotovili seznam osob určených k deportaci. Židé se nechali registrovat, vyplňovali nesčetné formuláře, odpovídali na mnohostránkové dotazníky ohledně svého majetku, aby byla usnadněna možnost jeho zabavení; pak se přesně dostavovali na shromaždiště a nastupovali do vlaků. Těch několik málo, kteří se pokusili uprchnout nebo ukrýt, bylo zajištěno zvláštními židovskými policejními oddíly. Pokud Eichmann mohl vidět, nikdo neprotestoval, nikdo neodmítl spolupracovat.“45

\footnotetext{
43 Tamt., str. 116-117.

44 H. Arendtová, Eichmann v Jeruzalémě, pře. M. Palouš, Praha 2019, str. 127.

45 Tamt., str. 128.
} 
Role židovských funkcionářủ byla v celém procesu klíčová, protože:

„Židovští představitelé spolehlivě vypracovávali seznamy osob, registrovali jejich majetek, vybírali od deportovaných poplatky na krytí nákladů spojených s jejich transportem a likvidací, udržovali záznamy o vyprázdněných bytech, organizovali policejní jednotky k zajištění transportovaných osob a udržení pořádku při nástupu do vlaků, a konečně, jako jakési závěrečné gesto, předávali zanechané a přesně evidované jmění židovské komunity k závěrečné konfiskaci.“46

Obecně tedy židovské komunity spolupracovaly s nacistickými autoritami do té míry, že „při své cestě na smrt polští Židé stěží viděli víc než hrstku Němců."“47

Kooperace židovské komunity při hladké přípravě a exekuci transportů do vyhlazovacích táborů je „,bezpochyby nejtemnější kapitolou veskrze temného prríběhu“. ${ }^{48}$ Dá se interpretovat či vysvětlovat mnoha způsoby - určitě však ne tak, jak interpretují vztah mezi mocí a obyvatelstvem Pullmann s Kolářem. Pro představu uvádím parafrázi Kolářova textu, který jsem citoval výše:

„,Moc' zajisté mohla někoho zatknout a poslat do koncentračního tábora. Avšak čistý nátlak nestačil k tomu, aby někoho přiměla stát se předsedou židovské rady, vedoucím speciálních židovských policejních oddílů nebo dobrovolným pomocníkem při evidenci majetku. Tyto ,nedobrovolně dobrovolné ‘ činnosti předpokládaly určitou míru (neideologického) přitakání stávajícímu aranžmá. Představovaly průsečík mezi tím, co chtěla ,moc‘ a tím, co odpovídalo individuálním zájmům členů židovské obce.“

Tato parafráze samozřejmě nemá za cíl srovnávat nacistický režim s režimem normalizačním, který byl nesrovnatelně humánnější. Jasně však demonstruje spornost Kolářova a Pullmannova přesvědčení, že za extenzivní a hladkou kooperací se musí skrývat implicitní přitakání nebo alespoň pasivní souhlas obyvatel s existujícím režimem. Pullmann s Kolářem zde jednoznačně přehlíží vliv politické moci na rozhodování jednotlivců.

\footnotetext{
46 Tamt., str. 131.

47 Arendtová zde cituje Roberta Pendorfa. Viz tamt., str. 130.

48 Tamt., str. 131.
} 
Kolaborace s politickou mocí může být totiž motivovaná mnoha důvody, jež nemají sebemenší souvislost s charakterem této moci či se vztahem kolaborujícího k ní. Tím nejvýznamnějším je samozřejmě motiv osobního zájmu. Postavení předsedy národního výboru stejně jako členství v židovských policejních oddílech přinášelo danému kolaborujícímu jistou míru reálné moci spojenou s výhodami pro něj a jeho blízké. I jednoznačné vnitřní odmítnutí existujícího politického aranžmá pak nemusí stačit, aby dotyčný tyto funkce odmítal. ${ }^{49}$ Podobnou roli může hrát idea služby komunitě. Myšlenka, že „když tu funkci nevezmu já, jistě přijde někdo výrazně horší," se vyskytuje ve všech problematických režimech, jejichž služebníci ji (s různou mírou sebeklamu) zhusta používají na ospravedlnění svých činů před sebou i ostatními. Každopádně platí, že kooperace společnosti s politickým režimem není automatickým důkazem podpory tohoto režimu. Politická moc (zejména u diktátorských režimů) disponuje prostředky, které jsou často schopny přesvědčit jednotlivce k extenzivní spolupráci nezávisle na její legitimitě.

Schopnost normalizačního režimu motivovat občany Československa ke kooperaci byla navíc zásadně podepřena stabilitou (z dobové perspektivy dokonce zdánlivou neměnností) tehdejšího geopolitického uspořádání. ČSSR se pevně nacházela $\mathrm{v}$ zóně sovětského vlivu, přátelství se Sovětským svazem bylo vepsáno v ústavě a podepřeno „dočasnou“ přítomností masivní okupační armády. To vše v situaci, kdy sovětské vedení opakovaně demonstrovalo svoji ochotu násilně zvrátit jakýkoli politický vývoj, který by vnímalo jako ohrožení svých zájmů. V této (zdánlivě) nezvratitelné situaci není nijak překvapivé, že otevřeně disidentský postoj byl valnou částí populace vnímán jako vlastně nepochopitelný. ${ }^{50}$ Nedá se z toho ovšem na žádné úrovni usuzovat nic o reálném přitakání, vnitřním přijetí či tiché podpoře stávajících poměrů, o vîre v legitimitu vlády ani nemluvě. Fakt kooperace nic nevypovídá o povaze, přijatelnosti či popularitě normalizačního režimu, a proto z něj nemůžeme vyvozovat žádné pozitivní hodnocení tehdejší politické situace.

49 Snad nejdrásavější umělecké ztvárnění dilemat spojených s kolaborací představuje slovenský film Obchod na korze (1965), ve kterém se hlavní hrdina ne zcela dobrovolně účastní procesu ,arizace“ židovského majetku.

50 Toto je fakt, na který opakovaně ve svých publikacích upozorňuje právě Pullmann. Viz nap̌r. P. Kolář - M. Pullmann (vyd.), Co byla normalizace?, str. 88-90. 


\section{„Hypernormalizovaný“ jazyk: dvě interpretace}

Při povrchním čtení by se mohlo zdát, že Pullmannův Konec experimentu a Havlova Moc bezmocných mají jen málo společného. První zmíněná je poměrně nedávná, odborná historická publikace, zatímco druhý text je volně psaná filosofická esej (a doplnit bych měl i skutečnost, že Pullmann ve své knize Havla ani jednou necituje). Při bližším pohledu však výše uvedené texty předkládají paralelní interpretace téhož fenoménu a mají stejnou ambici - snaží se analyzovat povahu ideologického jazyka v normalizační společnosti, popsat jeho každodenní fungování a různorodé funkce, které plní. Havlova a Pullmannova koncepce se samozřejmě v mnohém liší, zároveň však obě obsahují vícero styčných ploch, což činí jejich komparaci filosoficky zajímavou. V této kapitole se pokusím tyto konkurenční interpretace povahy a funkce ideologického jazyka popsat a kriticky zhodnotit. To poskytne další úhel pohledu na spor o charakter normalizace analyzovaný v tomto textu.

Václav Havel nabízí svou interpretaci funkce ideologického jazyka zhruba v třetí až deváté kapitole Moci bezmocných. ${ }^{51}$ Vychází, jak je známo, z podobenství o zelináři, který „umístil do výkladu mezi cibuli a mrkev heslo ,Proletáři všech zemí, spojte se!‘“.52 Podle Havla to udělal proto, že ,,je to jedna z tisíce maličkostí, které mu zajišt'ují relativně klidný život v souladu se společností “. 53 Jinak řečeno, ideologické heslo v zelinářově výloze má jednu základní funkci, a tou je signalizace zelinářovy konformity. Ta je zabalena do vzletné fráze, protože přímé sdělení jejího významu („Bojím se, a proto jsem bezvýhradně poslušný“) 54 by zelináře ztrapnilo a urazilo. U Havla je tedy jednou z funkcí ideologického jazyka nepřímá signalizace podřízení moci, která (právě kvůli své nepřímosti) může probíhat bez ztráty sebeúcty.

Zelinářovo gesto však neprobíhá v izolaci. „Taková hesla jsou i v jiných výkladech, na oknech, na střechách, na elektrických sloupech, prostě všude; tvoří cosi jako panoráma jejich každodennosti. “55 Ideologický

51 V následujícím textu budu citovat z vydání V. Havel, Moc bezmocných, in: týž, Moc bezmocných a jiné eseje, Praha 2017, str. 96-220. Úvahy o povaze a roli disentu, které tvoří nejrozsáhlejší část dané eseje, stojí mimo záběr tohoto článku, a proto je zde nebudu komentovat.

52 Tamt., str. 104.

53 Tamt., str. 105.

54 Tamt.

55 Tamt., str. 117-118. Kurziva v originálu. 
jazyk má proto nejenom funkci signalizace podřízení. Jeho extenzivní používání ve veřejném prostoru vtahuje jednotlivce dovnitř systému, činí jej jeho součástí. Zelinář svým gestem spoluvytváří panoráma nadšené a spokojené socialistické společnosti, a tím stvrzuje autoritu vlády komunistické strany ve veřejné sféře.

Avšak kulisy spokojené společnosti nadšené pro ideu socialismu, jež zelinář a jeho spoluobčané vytváří, zůstávají navzdory svému evidentnímu vlivu stále pouhými kulisami. ,Je to jakýsi svět ,zdání, který je vydáván za skutečnost.“ Normalizační člověk proto „musí žít ve lži “,56 což představuje samozřejmě problém, protože kulisy nadšené socialistické společnosti jsou tím pádem mimořádně křehké. Všudypřítomnost ideologického jazyka je tedy podle Havla schopna vytvořit silný obraz všeobecné konformity a participace, který má reálný vliv na společnost a její jednání. Avšak to, že ideologický jazyk nereflektuje skutečnost (či „pravdu“) je klíčovou slabostí celého „,posttotalitního“ uspořádání. Vybudovaný ideologický monolit je mimořádně křehký, a pokud je konfrontován se skutečností, má tendenci být „prozřen“ a zhroutit se.

Pullmann, jak jsem již naznačil výše, přichází s překvapivě podobným obrazem funkce a povahy ideologického jazyka. V první řadě se s Havlem shoduje v tom, že samotný obsah ideologických sdělení byl vlastně irelevantní. Stranické vedení v čase normalizace „spoléhalo na statické ideologické floskule“ ${ }^{57}$ které byly ve veřejném prostoru donekonečna opakovány. Základním pravidlem bylo, že ,autoritativní mluva ... není zpochybňována nebo komentována ve svém obsahu, nýbrž reprodukovaná ve své formě. “58 Ani pomyslný Pullmannův zelinář se svým heslem nesnaží nic říct o proletářích a jejich kooperaci. On a jeho spoluobčané svými gesty a sděleními totiž „nedeklarovali konkrétní fakty a názory, nýbrž vyjadřovali svůj souhlas s řádem věcí“ 59

Na rozdíl od Havla však Pullmann v opakování floskulí nevidí přetvářku, zdání, či dokonce lež. Tuto možnost (jak jsem předvedl výše) jeho výkladový rámec normalizace vůbec nepřipouští. Ideologické panoráma normalizační společnosti, na němž se podílí (téměř) všichni, interpretuje jako známku „konsensu“. Občané svými proklamacemi budují určitý typ společenské shody, která se stává klíčovou oporou režimu a dodává mu legitimitu.

\footnotetext{
56 Tamt., str. 110.

57 M. Pullmann, Konec experimentu, str. 91. Viz též tamt., str. 104-105.

58 P. Kolář - M. Pullmann (vyd.), Co byla normalizace?, str. 51.

59 Tamt., str. 53.
} 
Tato Pullmannova interpretace je samozřejmě nanejvýš sporná z důvodů, které jsem předestřel již v předchozí kapitole. Základní problém tkví v tom, že „předstírany“ “ konsensus ${ }^{60}$ není konsensem (podobně jako předstírané přátelství není prátelstvím) - a nedá se z něj usuzovat na reálný „,souhlas s řádem věcí“.

Pullmann však na obranu normalizačního ideologického jazyka uvádí dva další argumenty, které stojí za zkoumání. První z nich se věnuje roli tohoto jazyka při artikulaci nonkonformních postojů. Pullmann tvrdí, že ideologický jazyk v normalizační společnosti fungoval jako ,,autoritativní mluva“, která samotnou formou dodávala vážnost promlouvajícímu. Tato mluva sice sama o sobě nic neznamenala, ale užití správné formy pomáhalo promlouvajícímu např́ílad hájit i stanoviska vybočující z oficiální linie. „Vágnost ideologických floskulí totiž umožňovala lidem vnášet do autoritativní mluvy nové významy, požadavky a postoje.“61 Této flexibility ideologického jazyka si podle Pullmanna byli občané Československa dobře vědomi: ,,[O]ficiální hypernormalizované formulace [si] velká část obyvatelstva velmi dobře osvojila a na příslušných místech je i používala." 62 Bezobsažnost ideologického jazyka proto podle Pullmanna představovala jistou výhodu, protože jej občané mohli používat na obhajobu svých různorodých zájmů.

Do jisté míry má Pullmann pravdu. V určitých specifických situacích bylo snad možné hájit se oficiální ideologií i při následování nonkonformních cílů. ${ }^{63}$ Vnímat ideologický jazyk jako emancipační nástroj, jímž společnost mohla efektivně tlačit na režim, by však jistě bylo přepjaté. Zásadní problém spočíval v rozdílné schopnosti režimních elit a zbytku populace tento ideologický jazyk užívat. Průměrný občan jistě zvládal reprodukovat základní fráze, avšak kreativní užití postupně se proměňujícího jazyka marxismu-leninismu, který byl navíc rámcován Poučením z krizového vývoje, bylo často těžkou úlohou i pro profesionální komunistické kádry - jak ostatně opakovaně dokládá i Pullmann. ${ }^{64}$

60 M. Pullmann, Konec experimentu, str. 109.

61 P. Kolár - M. Pullmann (vyd.), Co byla normalizace?, str. 53.

62 M. Pullmann, Konec experimentu, str. 219.

63 Např́íklad studium Hegelovy filosofie mohlo být ospravedlněno jeho vlivem na Marxe, i když s marxismem mělo jen málo společného. Viz rozhovor Lukáše Rychetského a Matěje Metelce s Milanem Sobotkou: Naše doba vidí vše vyhroceněji. S Milanem Sobotkou o Hegelovi a výuce filosofie, A2, 18, 2020, online: https://www .advojka.cz/archiv/2020/18/nase-doba-vidi-vse-vyhroceneji (navštíveno 21. řŕjna 2020).

64 M. Pullmann, Konec experimentu, str. 214. 
Představa, že občané tento jazyk běžně a úspěšně používají při obhajobě svých zájmů ve střetu s režimem, je proto př́liš optimistická. Navíc je těžko představitelné, že by třeba i úspěšné zvládnutí ideologického jazyka situaci občanů nějak zásadně měnilo. Např́íklad snaha založit v nějakém závodě nezávislé komunistické odbory skutečně bojující za práva pracujících by na perzekuci narazila téměř okamžitě. Zaštitování se autoritou Marxe či Lenina by organizátorům pomohlo jen stěží. Jednoduše řečeno, vyjednávat s mocí není nikdy snadné, ale vyjednávat s ní v podmínkách diktatury, pomocí formalizovaného jazyka, jímž tato moc vždy mluví výrazně lépe než občan, je nezměrně těžší. Pullmannovo nadnesené tvrzení, že občané dokázali prostřednictvím ideologického jazyka přimět režim, aby plnil jejich „požadavky“ a respektoval jejich „postoje“, je proto nutné korigovat.

Druhým bodem Pullmannovy obhajoby ideologického jazyka v normalizaci je srovnávání tohoto jazyka s dalšími hodnotovými diskursy a jazykovými hrami, jež jsou nutně př́itomny v každé moderní společnosti. Cílem Pullmannovy argumentace je ukázat, že normalizační jazyk není ve své formě nijak unikátním vynálezem pozdního socialismu, ale je ekvivalentní jiným diskursům. Usuzovat z formalizovaného jazyka plného opakujících se floskulí na „Všeobecné pokrytectví“ (či dokonce ,život ve lži“") by proto podle něj bylo chybou. ${ }^{65}$

Pullmann má pravdu minimálně v tom, že samotné použití floskulí a formalizovaného jazyka je poměrně častým fenoménem. Každá společnost vytváří velké množství jazykových her, přičemž „veřejně, na pracovišti, $v$ různých kruzích přátel anebo doma" mluvíme často různými způsoby. ${ }^{66}$ Tato odlišná mluva i v dnešní době navíc často odráží mocenské poměry, očekávání nastavené „seshora“ a hodnoty, se kterými se ne vždy musíme plně ztotožňovat - a tedy jednoznačně není hodnotově neutrální. Dobrým příkladem zde může být jazyk grantových aplikací, které v dnešní době musí zdůrazňovat ,internacionalizaci“, vysoký „impakt“ a „outreach“, př́ípadně „,interdisciplinaritu“. Grantůchtiví pracovníci výzkumných institucí proto vtěsnávají své projekty do předem daného jazykového kódu, který by sami na popsání své práce nikdy nepoužili. Jejich „opakování předem daných floskulî“ však snad nemusíme hodnotit jako „všeobecné pokrytectví“. Hodnotit každý ne-plně-autentický projev nebo čin jako, „život ve lži“ by prozrazovalo nepochopení základních mechanismů mezilidské interakce.

65 Tamt., str. 217.

66 Tamt. 
Navzdory tomuto závěru však z Pullmannovy analýzy nevyplývá, že by normalizační jazyk byl jenom dalším kódem - že by byl ekvivalentní jiným specifickým formám jazyka, které používáme například u lékaře, v grantových žádostech či v dnešní politice. Je zde několik klíčových rozdílů, které znemožňují takto neutrální hodnocení normalizační mluvy. Právě na ně poukáži ve zbytku této kapitoly.

V porovnání s ostatními jazykovými kódy je význačná právě „bezobsažnost" normalizačního ideologického diskursu. I jazyk grantových výzev se navzdory floskulím opírá o reálné hodnoty (otevřenost vědy mezinárodní spolupráci, propojování jednotlivých, často uzavřených disciplín), kterým podstatná část akademiků, včetně autora tohoto textu, autenticky věří. Podobně i pravicový, konzervativní thatcherismus (což je Kolářův a Pullmannův př́íklad autoritativní mluvy zdánlivě ekvivalentní jazyku normalizace) ${ }^{67}$ se opíral o určitou, jakkoli problematickou, vizi společenského uspořádání. Ve strnulém normalizačním světě však (jak se na tom ostatně Pullmann s Havlem shodují) šlo zejména o konformitu. Funkcí ideologického jazyka bylo přimět společnost opakovaně deklarovat věrnost komunistickému režimu v situaci, kdy reálnou podporu tento režim neměl. Výsledná „falešnost““, „zdání“ či rovnou „lež“, která skrze vytvářené „,panoráma“ prostupuje celým veřejným prostorem, není srovnatelná s žádnými jinými jazykovými hrami a kódy, které Pullmann uvádí. Jeho neutrální hodnocení normalizačního jazyka jako pouhého dalšího příkladu hodnotového diskursu proto není na místě.

Druhým problémem je mocenský kontext, ve kterém normalizační ideologický jazyk působil. I kdybychom přiznali, jak tvrdí Pullmann, že „hesla ,demokracie‘, ,trhu“, ,individuálních šancí‘ a ,tvrdé práce“ dnes plní podobnou funkci, jakou měli jejich normalizační předchůdci ,socialismus“, ,plánování (což není pravda minimálně z důvodů, které jsem vyložil v předešlém odstavci), zůstává zde problém okolností, za nichž se tento diskurs protlačil do veřejného prostoru a udržoval se v něm. Jazyk demokracie a individuálních šancí se prosadil v podmínkách svobody slova. Prosazování alternativních hodnotových systémů bylo a je možné jak ve veřejném diskursu, tak $\mathrm{v}$ politice, kde dlouhodobě působí vícero subjektů vysloveně skeptických jak vůči hodnotám liberální demokracie, tak vůči ,trhu“.

67 P. Kolář - M. Pullmann, Co byla normalizace? str. 56.

68 M. Pullmann, Konec experimentu, str. 226. 
Pullmann a Kolář jako by tuto rozdílnost neviděli. Při srovnávání Husáka a Thatcherové např́klad konstatují, že se těmto státníkům podařilo vlastně totéž - ,stigmatizovat alternativy“ k vlastnímu hodnotovému diskursu. Pak jen jaksi mimochodem dodávají, že v jednom př́ípadě se tak dělo „pomocí represivního legalismu, tedy kriminalizováním opozice“ a v druhém případě „mediálním tlakem“. ${ }^{69}$ To však představuje naprosto zásadní rozdíl. Thatcherové vláda čelila reálné opozici s reálnou společenskou podporou, která byla připravená převzít moc $\mathrm{v}$ momentě, kdy společnost hodnoty thatcherismu odmítne ve férových volbách. Kromě toho samozrejmě thatcherovský diskurs nebyl všudypř́itomný a netvořil žádné „,panoráma“ života Anglie osmdesátých let. Londýnští zelináři mezi cibuli a mrkev nevěšeli nápisy „Trh vyřeší všechno“ a nikdo po nich ani takové konání nevyžadoval. Normalizační jazyk je nesrovnatelný s jinými jazykovými kódy jak svou extenzí (tedy téměř všudypř́ítomností), tak tím, že jeho monopol byl podepřen celým mocenským uspořádáním, a dokonce vepsán do ústavy, bez možnosti kritiky.

Normalizační diskurs tedy není oddělitelný od režimu, jenž jej vynucoval. Aby plnil svou funkci, potřeboval represivní aparát, který potlačoval všechny alternativy a nutil (či ,motivoval“) lidi jej používat. Když Pullmann hovoří o „křehkosti“ normalizačního „konsensu“,$^{70}$ odkazuje dle mého názoru ke stejnému faktu jako Havel: že bez nucené konformity monolit ideologického jazyka ,působí dojmem, že je z papíru a že se začne nezadržitelně trhat a rozpadat".${ }^{71}$ Právě tato křehkost je znakem, že normalizační diskurs v konečném důsledku nereflektoval nastavení společnosti, byl společnosti vnucen, a vymizel beze zbytku, jakmile nebyl mocensky podepírán.

\section{Závěr: Moc státu v podmínkách absence legitimity}

Závěrem se pokusím načrtnout vůči Pullmannovi alternativní pohled na interakci mezi komunistickou mocí a normalizační společností. V jistém smyslu budu dokonce postupovat přesně opačně. Zatímco Pullmann usuzuje z dlouhodobé stability a široké kooperace na přijetí či legitimitu normalizačního režimu, já nastíním, proč právě absence legitimity ved-

69 P. Kolář - M. Pullmann (vyd.), Co byla normalizace?, str. 57.

70 M. Pullmann, Konec experimentu, str. 14.

71 V. Havel, Moc bezmocných, str. 130. 
la ke krizi a následnému zhroucení socialistického režimu v Československu.

Legitimita politického režimu, podpora veřejnosti, či (ne)existence společenského konsensu na mocenském uspořádání totiž hrají v politických vztazích zásadní, i když mimořádně komplexní roli. Komplikovaný vztah mezi vládou, ospravedlněním moci a obyvatelstvem analyzuje např́́klad David Beetham ve své mimořádně vlivné knize The Legitimation of Power. ${ }^{72}$ Beetham napříc svou knihou ukazuje, jak ztotožnění obyvatelstva s politickým režimem umožňuje dané vládě efektivně jednat. Zdaleka ne všechna politická opatření jsou totiž př́ímočaře vynutitelná. Spolupráce občanů nad rámec toho, co režim sám dokáže vysledovat, je často klíčem k úspěchu vládních opatření. ${ }^{73}$ Stejná situace platí obráceně pro nelegitimní režimy, které (často navzdory obrovskému represivnímu aparátu) mají velké potíže se zaváděním jistého typu opatření - zejména pokud tato opatření vyžadují iniciativu, riziko, vlastní rozhodování či zapálení pro věc. Podpora vlády či existence jistého společenského konsensu je tedy pro Beethama klíčovou kategorií, protože vytváří podmínky, díky nimž je možné provádět komplexní opatření či reformy - tedy úspěšně vládnout.

Pokud Beethamovy myšlenky aplikujeme na Československo, musíme souhlasit s Pavlem Kolářem, když tvrdí, že je nutné „,poopravit ... představu, že by společnost v komunistické diktatuře byla úplně bezmocná“. ${ }^{74}$ Platí také, jak tvrdí Pullmann, že občané byli schopni „mařit oficiální cíle“. ${ }^{75}$ Je však důležité specifikovat, jakou moc měla společnost a jakým způsobem byla schopna mařit oficiální cíle. To se nedělo přímou opozicí, protesty či nedodržováním pravidel a doporučení. Normalizační režim v Československu byl schopen efektivně přimět občany, aby vstávali na šestou do práce, účastnili se schůzí, průvodů a voleb, prrípadně se „dobrovolně“ angažovali v brigádách socialistické práce. To vše byly veřejné, kontrolovatelné aktivity, které si režim bez problémů zvládal „,pohlídat“, a proto je nebylo možné přímočaře „mařit".

Problém nastal jinde. Mezi historiky panuje konsensus - se kterým se Pullmann také ztotožňuje -, že období po roce 1968 charakterizovalo

72 D. Beetham, The Legitimation of Power, New York 1991.

73 Tento fakt se mimochodem jasně ukazuje v době pandemie COVID-19.

74 P. Kolár - M. Pullmann (vyd.), Co byla normalizace?, str. 117.

75 Tamt., str. 33. 
zásadní přelití aktivity do soukromé sféry. Lidé se věnovali rodině (proto „Husákovy děti“), chalupám či automobilům, vzkvétala trampská kultura a podobně. Autentická angažovanost v (široce definované) veřejné sféře do značné míry vymizela. Obyvatelé Československa si „odbyli““ svou práci, své schůze, brigády a pochody a pak se uzavírali do soukromého světa, kde žili svůj ,,normální“ život. ${ }^{76}$

Jakmile však rozhodující většina populace vstupuje do veřejného prostoru (čímž zde myslím i sféru práce a zaměstnání) pouze s cílem „si to nějak odbýt“", dlouhodobým výsledkem bude vždy jen jediné: společenská, politická a ekonomická stagnace. Dobré svědectví toho, že hlavní problémy socialistické ekonomiky byly přesně tohoto typu, podává právě Pullmann, když ve svém Konci experimentu analyzuje dobový jazyk. Když se režim snažil zjistit, co brzdí socialistickou ekonomiku a co tedy má být cílem „přestavby“, jež měla vyvést hospodářství z krize, opakovaně narážel na to, že podstata problémů „spočívala ,v lidech“ - jejich ,opatrnictví', ,alibismu“ a ,nerozhodnosti““. Klíčová byla „neschopnost lidí zbavit se ,administrativních a byrokratických přístupů ““. ${ }^{77}$ Cílem přestavby tedy mělo být ,napravení , lidských vlastností “ jako ,pohodlnost“ či ,sobeckost ““. ${ }^{78}$ Zásadní bylo ,podněcování tvořivé aktivity lidí“ ${ }^{79}$ Naopak se bojovalo s ,,lajdáctvím“, ,lhostejností", ,nehospodárností‘, ,byrokratismem“" atd. ${ }^{80}$ Takto bychom mohli citovat ještě dlouho. Celkový obrázek by se však neměnil. Dál by ukazoval situaci, kdy se valná většina obyvatelstva angažuje v práci (či ve veřejném prostoru obecně) jenom do té míry, do jaké to považuje za nezbytně nutné, aby na sebe neupoutala nechtěnou pozornost. Jakékoli očekávání navíc se občanům neomylně a efektivně daří „,mařit“. Dlouhodobým a neodvratným výsledkem dané situace je pak neschopnost režimu efektivně vládnout spojená s krizí a stagnací nejen ekonomiky, ale i společnosti jako celku.

Obecně tedy můžeme příběh Československa v letech 1968-1989 popsat právě pomocí kategorie legitimity. Invaze vojsk Varšavské smlouvy měla za následek výměnu populární a široce přijímané Dub-

\footnotetext{
76 Jestli je však opuštění veřejného prostoru a pouze soukromý život skutečně „normální“, je otázka přesahující rámec tohoto textu.

77 M. Pullmann, Konec experimentu, str. 130.

78 Tamt.

79 Tamt., str. 60-61.

80 Tamt., str. 24.
} 
čekovy vlády za normalizační Husákův režim. Ten byl schopen velice efektivně nastolit „,normální“ poměry, při nichž fungovaly obchody či úřady, lidé chodili do práce a téměř nikdo otevřeně neprotestoval. Daná situace však měla jednu zásadní chybu: ve společnosti absentovala ona Weberova „víra v legitimitu“ politického uspořádání ze strany obyvatelstva. Panoráma ideologických sdělení, jež rámcovalo celý veřejný prostor, tuto absenci nemohlo nijak nahradit. Přímým následkem nelegitimní vlády bylo u naprosté většiny obyvatelstva stáhnutí se z veřejného prostoru a ztráta zájmu o vše, co přesahovalo meze jejich soukromého života. Neexistující motivace dělat cokoli nad rámec seshora určených (a kontrolovatelných) očekávání neomylně vedla do krize, kterou strnulý normalizační režim nedokázal řešit. V momentě prvního uvolňování poměrů se tato absence legitimity ukázala v plné mîre, a když bylo jasné, že vláda již není podepřena ochotou Sovětského svazu intervenovat, režim neodvratně padl. ${ }^{81}$

Filosofie je polemická disciplína, ve které může snaha o artikulaci nesouhlasu či rozdílnosti zastávaných názorů často skrývat to, na čem se obě strany sporu shodnou. Konkrétně v tomto textu bylo mou ambicí ukázat limity a problémy Pullmannova hodnocení normalizace. Jeho snaha o neutrální vykreslení normalizačního diskursu či o obhajobu legitimity tehdejšího režimu, údajně podepřeného tichým souhlasem společnosti, není, jak jsem se snažil vykreslit, obhajitelná. Konec experimentu však navzdory tomu považuji za fascinující a jednoznačně př́nosnou knihu. Detailnost, s níž Pullmann vykreslil erozi ideologického jazyka v pozdních osmdesátých letech a s tím související ztrácející se schopnost normalizačních elit artikulovat společenské problémy, nemá minimálně v českém prostředí obdoby. Také jeho argumentace, že společenská vážnost „disentu“ byla až do roku 1989 zanedbatelná, je do značné míry přesvědčivá. Jeho následná teze, že pro pochopení každodenního života či vnitřní dynamiky normalizační společnosti není zkoumání osudů úzké skupiny disidentů nijak zvlášt' přínosné, pak představuje důležitý signál směrem dovnitř historické komunity k reorientaci výzkumu naší nedávné minulosti.

Každopádně platí, že „charakter normalizace“ bude i v budoucnosti ožehavým tématem vyvolávajícím ostré spory. Například i proto, že existují oblasti, ve kterých můžeme normalizační společnost hodnotit

81 Pro širší analýzu toho, jak absence legitimity způsobila neschopnost socialistických režimů efektivně vládnout, viz D. Beetham, The Legitimation of Power, str. 185-189. 
jednoznačně pozitivně, a to i ve srovnání se současností. ${ }^{82}$ Avšak pokusy o celkové, radikální přehodnocení normalizace, jak se o to pokouší Pullmann, jsou odsouzeny k nezdaru.$^{83}$

Matej Cíbik

82 Např́ḱlad v otázce rodové rovnosti. Viz B. Havelková, Gender Equality in Law. Uncovering the Legacies of Czech State Socialism, Oxford 2017.

83 Tato publikace byla podpořena v rámci projektu OP VVV „Centrum pro etiku jako studium hodnoty člověka“", reg. č. CZ.02.1.01/0.0/0.0/15_003/0000425, spolufinancovaného z Evropského fondu pro regionální rozvoj a státního rozpočtu České republiky. Za zásadní připomínky při psaní tohoto textu děkuji zejména Jakubu Jirsovi, Ondřeji Krásovi, a hlavně Michalu Pullmannovi, jehož ochoty text připomínkovat navzdory jeho kritickému vyznění si velice cením. 